\title{
PENGARUH METODE PEMBELAJARAN KOOPERATIF DAN MINAT BELAJAR TERHADAP KEMAMPUAN BERPIKIR KRITIS MATEMATIKA SISWA
}

\author{
GITA KENCANAWATY \\ Program Studi Teknik Informatika, Fakultas Teknik, Matematika dan IPA \\ Universitas Indraprasta PGRI \\ Email : gita_kencanawaty@yahoo.com
}

\begin{abstract}
The purpose of this study is to determine the effect of cooperative learning and the interest of learning the mathematics by students' critical thinking skills. The method used is an experimental method. A sample size of 60 students consisting of 30 students of experimental class and 30 students of control class, the sampling technique used is cluster sampling. The research instrument used is the test of preferential interest in learning (30 questions) and the ability to think critically shaped Mathematical descriptions, as many as 10 questions that tested the validity by the reliability coefficient of 0.884 and 0.707 Data were analyzed by using ANOVA two ways. The results showed: (1) There is a significant relationship between the method of learning on students 'critical thinking skills Mathematics of $F_{\text {hitung }}=111.647$ and Sig $=0.000<0.05$, (2) There is a significant relationship between interest in learning to students' critical thinking skills Mathematics $F_{\text {hitung }}=4.619$ and Sig $=0.036<0.05$, (3) There is no significant interaction effect between learning and interest in learning the mathematics students' critical thinking skills of $F_{\text {hitung }}=3.207$ and Sig $=0.079>0.05$. The results of this study are useful for the improvement of mathematics critical thinking skills in students by use of cooperative learning method, such as the pair of checks and think pair share classes in addition to the efforts encouragement to students to be more interested and liked math.

Keywords: cooperative learning method, interest, critical thinking
\end{abstract}

\section{PENDAHULUAN}

Matematika dipandang sebagai ilmu dasar segala bidang ilmu pengetahuan merupakan hal yang sangat penting untuk kita ketahui.Oleh sebab itu, matematika perlu diajarkan di semua jenjang pendidikan formal, mulai dari pendidikan dasar hingga perguruan tinggi.Pentingnya matematika bisa dilihat dari manfaat dan kegunaan matematika dalam kehidupan sehari-hari, juga bagi pengembang ilmu pengetahuan. Oleh karena itu, penyempurnaan kurikulum terus dilakukan oleh Depdiknas, antara lain dengan memasukkan kemampuan berpikir kritis, kreatif, logis, analitis, dan sistematis sebagai standar kompetensi pelajaran matematika.

Kemampuan berpikir kritis matematika sangat diperlukan oleh siswa mengingat bahwa matematika merupakan pengetahuan yang eksak, benar, dan langsung menuju sasaran sehingga membentuk disiplin dalam berpikir.Mata pelajaran matematika berfungsi untuk mengembangkan kemampuan berkomunikasi dengan menggunakan bilangan-bilangan dan simbol-simbol serta ketajaman penalaran yang dapat membantu memperjelas dan menyelesaikan permasalahan dalam kehidupan sehari-hari.

Kemampuan berpikir kritis matematika siswa dapat dipengaruhi oleh beberapa hal, yaitu strategi atau teknik guru dalam pembelajaran, minat belajar, motivasi belajar, dan lain-lain. Seperti yang kita ketahui, bahwa matematika sebagai mata pelajaran di sekolah, baik tingkat dasar maupun tingkat lanjutan 
tinggi, sebagai pelajaran yang kurang disenangi oleh siswa karena merupakan mata pelajaran yang dianggap oleh sebagian siswa sulit.

Penguasaan siswa terhadap matematika dapat dilihat dari hasil belajar siswa.Secara umum, rendahnya hasil belajar siswa dalam pelajaran matematika dipengaruhi oleh banyak faktor. Faktor-faktor tersebut bersumber pada kemampuan siswa, materi pelajaran, media pembelajaran atau alat bantu untuk belajar, guru, metode penyampaian atau metode mengajar, motivasi, minat belajar, dan lain-lain. Dalam proses pembelajaran, guru harus memiliki strategi agar siswa dapat belajar secara efektif dan efisien, serta minat belajar pada diri siswa pun akan meningkat.

Berpikir kritis tidak dapat diajarkan melalui metode ceramah, karena berpikir kritis merupakan proses aktif. Keterampilan intelektual berpikir kritis mencakup berpikir analisis, berpikir sintesis, berpikir reflektif, dan sebagainya harus dipelajari melalui aktualisasi penampilan (performance). Berpikir ktitis dapat diajarkan melalui kegiatan labolatorium, inkuiri, term paper, pekerjaan rumah yang menyajikan berbagai kesempatan untuk menggugah berpikir kritis, dan ujian yang dirancang untuk mempromosikan keterampilan berpikir kritis, yang salah satunya adalah kegiatan pembelajaran berkelompok. Kegiatan pembelajaran berkelompok ini dapat menggunakan metode pembelajaran kooperatif, sehingga kemampuan berpikur kritis siswapun akan meningkat.

Pada umumnya, guru menggunakan metode pembelajaran klasikal sehingga kebutuhan siswa secara individu kurang terpenuhi dan mengakibatkan rendahnya minat belajar siswa. Oleh karena itu, proses pembelajaran masih tampak adanya kecenderungan minimalnya peran dan keterlibatan siswa. Hal ini justru membuat siswa tidak memahami materi sehingga minat terhadap pelajaran tersebut akan berkurang.Dalam proses pembelajaran, guru memiliki peran yang sangat penting. Guru mengajar tidak cocok dan sukar dimengerti siswa, maka akan membuat siswa yang pada awalnya menyenangi pelajaran matematika menjadi tidak acuh sikapnya.Untuk itu diperlukan metode yang tepat agar minat belajar siswa dapat meningkat, karena setiap metode dalam pembelajaran mempunyai keunggulan dan kelemahan, bukan hanya dari segi tujuan tetapi juga terhadap kondisi dan situasi dalam proses pembelajaran. Dengan kata lain, suatu proses pembelajaran merupakan suatu kondisi dimana interaksi antar siswa dan guru harus dapat berjalan dengan baik demi tercapainya tujuan pendidikan. Interaksi yang baik akan mencapai tujuannya apabila suasana menyenangkan terjadi dalam proses pembelajaran dan bermakna bagi siswa dan guru sehingga tidak terdapat lagi siswa yang membenci matematika, karena suasananya sudah tidak menakutkan dan menyenangkan bagi mereka.

Metode pembelajaran yang baik haruslah disesuaikan dengan karakteristik siswa, karena setiap siswa memiliki kebutuhan yang berbeda-beda. Salah satu metode pembelajaran yang digunakan adalah metode pembelajaran yang mengutamakan kerjasama antar siswa dalam mencapai tujuan pembelajaran.Menggunakan metode pembelajaran kooperatif berarti mengubah pembelajaran dari peran yang berpusat pada guru ke pengelolaan siswa dalam kelompok-kelompok kecil. Pembelajaran kooperatif ini mengajarkan siswa untuk bekerjasama dan berbagi ide dalam memecahkan suatu masalah, berdiskusi serta membahas apabila terdapat perbedaan pendapat. Pada metode pembelajaran ini, guru berperan sebagai fasilitator, yaitu guru memberikan kesempatan seluasluasnya bagi siswa untuk memecahkan masalah-masalah, namun para siswa tetap 
berada dalam bimbingannya.Terdapat beberapa tipe dalam pembelajaran kooperatif.

Diantara beberapa tipe metode pembelajaran kooperatif terdapat satu pembelajaran kooperatif yang menarik dan dapat mengaktifkan para siswa serta memengaruhi pola interaksi siswa dalam pembelajaran di kelas, yaitu tipeThink Pair Share. Keterlibatan siswa secara aktif dalam proses pembelajaran tentu saja dapat menciptakan proses pembelajaran menjadi lebih kondusif dan menyenangkan. Selain itu, tipe ini lebih mudah dan cepat dalam membentuk kelompok dan dapat meningkatkan keterlibatan atau partisipasi siswa dalam proses pembelajaran, serta memberikan kesempatan lebih untuk kontribusi masing-masing kelompok. Proses pembelajaran tersebut diharapkan dapat meningkatkan minat belajar siswa.

Minat belajar siswa akan tumbuh dengan adanya beberapa faktor yang menggerakkan dan membangkitkannya, salah satunya adalah dengan adanya proses belajar yang menyenangkan. Hal ini dapat menyebabkan siswa menjadi lebih tertarik pelajaran tersebut, dengan demikian tumbuhlah minat belajar pada diri siswa. Dengan terciptanya proses pembelajaran yang menyenangkan, diharapkan dapat meningkatkan minat belajar siswa terhadap mata pelajaran matematika. Minat belajar sangat diperlukan dalam melakukan suatu perbuatan untuk mencapai tujuan pembelajaran itu sendiri. Sebab perbuatan dengan disertai minat dapat mendorong seseorang untuk berbuat lebih, yaitu lebih giat dan lebih baik. Seseorang yang belajar penuh dengan minat akan menguntungkan kegiatan belajar itu sendiri, sebab belajar akan terasa lebih menyenangkan dan menarik. Dengan demikian, apapun yang dipelajari akan terasa mudah untuk dipahami dan mudah diingat.

Penggunakan strategi, pendekatan, metodeyang tepat dan dengan adanya minat belajar, hal ini dapat memengaruhi kemampuan berpikir kritis matematika pada siswa.Berdasarkan penjelasan dari latar belakang di atas, maka penulis akan melakukan penelitian dengan judul "Pengaruh Metode Pembelajaran Kooperatif dan Minat Belajar Terhadap Kemampuan Berpikir Kritis Matematika Siswa (Eksperimen pada SMP Negeri Se Kecamatan Tebet, Jakarta Selatan)".

\section{TINJAUAN PUSTAKA}

\section{Kemampuan Berpikir Kritis Matematika}

Berpikir kritis adalah usaha yang sengaja dilakukan secara aktif, sistematis, dan mengikuti prinsip logika serta mempertimbangkan berbagai sudut pandang untuk mengerti dan mengevaluasi suatu informasi dengan tujuan apakah informasi itu diterima, ditolak atau ditangguhkan penilaiannya. Menurut Angelo (1995:59) berpikir kritis adalah mengaplikasikan rasional, kegiatan berpikir yang tinggi, meliputi kegiatan menganalisis, mensintesis, mengenali permasalahan dan pemecahannya, menyimpulkan serta mengevaluasi. Berdasarkan pendapatpendapat di atas dapat disimpulkan bahwa berpikir kritis adalah mengaplikasikan rasional, kegiatan berpikir yang tinggi, meliputi kegiatan menganalisis, mensintesis, mengenali permasalahan dan pemecahannya, menyimpulkan serta mengevaluasi.

Kemampuan berpikir kritis seseorang dalam suatu bidang studi tidak dapat terlepas dari pemahamannya terhadap materi bidang studi tersebut, maka sesorang harus menguasai materi minimal $80 \%$ agar dapat berpikir kritis dalam suatu 
pelajaran. Namun, sebagaimana kita ketahui bahwa matematika bersifat aksiomatik, abstrak, formal, dan deduktif. Karenanya wajar jika matematika termasuk mata pelajaran yang dianggap sulit oleh siswa pada umumnya yang tahap berpikirnya belum formal dengan bakat serta kemampuannya yang bervariasi. Masih rendahnya kualitas hasil belajaran siswa dalam matematika merupakan indikasi bahwa tujuan yang ditentukan dalam kurikulum matematika belum tercapai secara optimal. Agar tujuan tersebut dapat tercapai sesuai yang diinginkan, maka salah satu caranya adalah dengan melaksanakan proses pembelajaran yang berkualitas.

Kemampuan berpikir kritis matematika yang digunakan dalam penelitian ini mencakup: Kemampuan mengidentifikasi asumsi yang diberikan; Kemampuan merumuskan pokok-pokok permasalahan; Kemampuan menentukan akibat dari suatu ketentuan yang diambil; Kemampuan mengungkap teorema dalam menyelesaikan masalah; Kemampuan berpikir kritis matematika adalah kemampuan individu untuk melihat dan menganalisa fakta, mengorganisasikan ideide, mempertahankan pendapat, membuat perbandingan, membuat kesimpulan, mempertimbangkan argumen dan memecahkan masalah matematika yang ditandai dengan sifat-sifat dan bakat kritis yaitu mempunyai rasa ingin tahu yang tinggi imajinatif dan selalu tertantang oleh kemajemukan, berani mengambil resiko.

\section{Metode Pembelajaran Kooperatif}

Menurut Suherman (2003:260), Pembelajaran kooperatif mencakup suatu kelompok kecil siswa yang bekerja sebagai sebuah tim untuk menyelesaikan sebuah masalah, menyelesaikan tugas atau, mengerjakan sesuatu untuk mencapai tujuan bersama lainnya. Kelompok kecil yang dimaksud adalah kelompok yang terdiri dari 2-5 orang dengan kemampuan dan latar belakang yang berbeda. Metode pembelajaran kooperatif tidak sama dengan belajar kelompok biasa. Ada unsurunsur yang membedakannya dengan belajar kelompok biasa. Menurut Lie dalam buku Cooperative Learning di Ruang-Ruang Kelas (2002:30) ada lima unsur metode pembelajaran kooperatif yang harus diterapkan adalah : (1) Saling ketergantungan positif, (2) Tanggung jawab perseorangan, (3)Tatap muka, (4) Komunikasi antar anggota, (5) Evaluasi proses kelompok. Prosedur penskoran dapat dilakukan dengan cara seperti tabel berikut:

Tabel 1. Perhitungan Skor Perkembangan

\begin{tabular}{lc}
\multicolumn{1}{c}{ Nilai Tes } & $\begin{array}{c}\text { Skor } \\
\text { Perkembangan }\end{array}$ \\
\hline Lebih dari 10 poin di bawah skor awal $\rightarrow(\mathrm{x}<\mathrm{y}-10)$ & 0 poin \\
10 poin di bawah sampai 1 poin di bawah skor awal $\rightarrow(\mathrm{y}-10<\mathrm{x}<\mathrm{y})$ & 10 poin \\
Skor awal sampai 10 poin di atas skor awal $\rightarrow(\mathrm{y}<\mathrm{x} \leq \mathrm{y}+10)$ & 20 poin \\
Lebih dari 10 poin di atas skor awal $\rightarrow(\mathrm{x}>\mathrm{y}+10)$ & 30 poin \\
Nilai sempurna (tanpa memperhatikan skor awal) $\rightarrow(\mathrm{x}=100)$ & 30 poin \\
\hline Keterangan: $\quad \mathrm{x}=$ nilai tes $\mathrm{y}=$ skor awal
\end{tabular}

Trianto (2007:56) mengatakan bahwa skor kelompok dihitung dengan membuat rata-rata skor perkembangan anggota kelompok. Sesuai dengan rata-rata skor perkembangan kelompok seperti tercantum pada tabel berikut: 
Tabel 2. Tingkat Penghargaan Kelompok

\begin{tabular}{cc} 
Rata-rata Tim. & Predikat \\
\hline $0 \leq \mathrm{x} \leq 5$ & - \\
$5 \leq \mathrm{x} \leq 15$ & Tim Baik \\
$15 \leq \mathrm{x} \leq 25$ & Tim Hebat \\
$25 \leq \mathrm{x} \leq 30$ & Tim Super \\
\hline
\end{tabular}

Berdasarkan uraian di atas dapat disimpulkan bahwa metode pembelajaran kooperatif adalah pola belajar kelompok dengan cara kerjasama antar siswa yang dapat mendorong timbulnya gagasan atau ide yang mengutamakan kerjasama di antara siswa untuk mencapai tujuan pembelajaran yang lebih bermutu dan meningkatkan kreativitas siswa.

\section{Metode Pembelajaran Kooperatif Tipe Think Pair Share}

Think Pair Share merupakan salah satu metodesederhana yang dapat digunakan dalam pembelajaran matematika.Tipe sederhana ini dikembangkan oleh Frank Lyman dari University of Maryland. Menurut Susan Ledlow, Think Pair Share (TPS) merupakan tipe sederhana yang dapat membuat siswa lebih aktif dalam pembelajaran (Ledlow, 2010:68). Proses think dalam tipe ini mendorong siswa untuk aktif secara mental dalam pembelajaran, yaitu dengan membangun ideide untuk menyelesaikan permasalahan yang diberikan oleh guru. Pada tahap ini terdapat tiga tahap yang sangat penting. Tahap pertama siswa dituntut memikirkan beberapa permasalahan yang diberikan secara individual (think). Setelah itu siswa berpasangan dan berdiskusitentang pemecahan masalah tersebut (pair). Kemudian hasil diskusi pasangan akan dibagikan oleh siswa pada seluruh kelas (share).

Menurut Lie (2002:58), pelaksanaan Think Pair Share dalam kelas, sebagai berikut: (1) Guru membagi siswa secara berpasangan (berdua) dan memberikan tugaskepada semua kelompok. (2) Setiap siswa memikirkan dan mengerjakan tugas tersebut secara individu (sendiri). (3) Siswa diberi kesempatan untuk berdiskusi dengan pasangannya. (4) Guru memanggil siswa secara acak untuk membagikan hasil diskusi mereka dengan pasangan di depan kelas.

Pembelajaran dengan tipe TPS ini terdiri dari empat tahap. Pada tahap pertama, pembelajaran dimulai dengan penyampaian tujuan pembelajaran oleh guru. Guru juga memberikan motivasi pada siswa agar siswa tertarik pada materi yang akan diberikan. Selanjutnya guru mengantarkan dan menjelaskan konsepkonsep dasar pada siswa dengan diskusi dan tanya jawab. Pada tahap kedua, guru membagikan lembar kerja siswa yang berisi soal-soal yang harus diselesaikan siswa. Secara individu siswa mencoba untuk menggali ide-ide mereka untuk mencari solusi dari permasalahan yang diberikan. Tahap ini disebut tahap think. Siswa didorong untuk menyelesaikan permasalahan dalam lembar kerja secara individu sebelum didiskusikan dengan pasangannya. Pada tahap ketiga, guru mengumpulkan siswa dengan pasangan masing-masing. Bersama pasangan, siswa mendiskusikan hasil kerja dan mencari penyelesaian yang tepat (pair). Pada tahap ini siswa dilatih untuk mengomunikasikan ide mereka pada siswa lain dan mengambil keputusan yang tepat.Pada tahap terakhir, setelah proses diskusi selesai, guru memanggil beberapa siswa secara acak untuk mempresentasikan hasil kerja pada semua siswa (share). Pada akhir pembelajaran guru membenarkan konsepkonsep siswa yang salah dan mmbuat kesimpulan. 
Berdasarkan uraian di atas dapat disimpulkan bahwa metode pembelajaran kooperatif think pair share adalah metode yang memberi siswa kesempatan untuk bekerja sendiri dan bekerjasama dengan orang lain/diskusi dalam pemecahan masalah, sehingga terciptanya suasana belajar yang lebih hidup, aktif, kreatif, efektif, dan menyenangkan.

\section{Minat Belajar}

Minat berperan sangat penting dalam kehidupan peserta didik dan mempunyai dampak yang besar terhadap sikap dan perilaku peserta didik. Siswa yang memiliki minat terhadap kegiatan pembelajaran akan berusaha lebih keras dibandingkan siswa yang kurang berminat. Slameto (2003:57) berpendapat bahwa minat adalah kecenderungan yang tetap untuk memerhatikan dan mengenang beberapa kegiatan. Kegiatan yang diminati siswa, diperhatikan secara terusmenerus yang disertai dengan rasa senang dan diperolehnya rasa kepuasan. Lebih lanjut dijelaskan bahwa minat adalah suatu rasa suka dan ketertarikan pada suatu hal atau aktivitas, tanpa ada yang menyuruh. Berikut ini beberapa cara yang dapat dilakukan pengajar untuk meningkatkan minat belajar siswa, yaitu : memberikan informasi kepada siswa mengenai hubungan antara suatu bahan pengajaran yang akan diberikan dengan bahan pengajaran yang lalu serta menguraikan kegunaannya bagi siswa di masa akan dating, menghubungkan bahan pengajaran dengan suatu berita sensasional yang sudah diketahui banyak siswa, dan menggunakan insentif sebagai alat yang dipakai untuk membujuk seseorang agar melakukan sesuatu yang tidak mau melakukannya atau yang tidak dilakukan dengan baik (Slameto, 2010:181).

Dalam belajar diperlukan suatu pemusatan perhatian agar apa yang dipelajari dapat dipahami. Sehingga siswa dapat melakukan sesuatu yang sebelumnya tidak dapat dilakukan. Terjadilah suatu perubahan kelakuan. Perubahan kelakuan ini meliputi seluruh pribadi siswa; baik kognitif, psikomotor maupun afektif.Untuk dapat meningkatkan minat belajar, maka proses pembelajaran di kelas dapat dilakukan dalam bentuk kegiatan siswa bekerja dan mengalami apa yang ada di lingkungan secara berkelompok.

\section{METODE PENELITIAN}

Pada penelitian ini menggunakan metode eksperimen, yaitu dengan memberikan jenis perlakuan yang berbeda pada dua kelompok belajar siswa. Satu kelompok dijadikan sebagai kelompok eksperimen, yaitu diberikan perlakuan pembelajaran Matematika dengan metode Think Pair Share, sedangkan kelompok yang satu lagi sebagai kelompok kontrol dengan perlakuan metode pembelajaran Konvensional. Dari masing-masing kelompok kemudian dibagi ke dalam siswa memiliki minat belajar tinggi dan siswa memiliki minat belajar rendah.Penelitian ini mengandung 2 validitas, yaitu validitas internal dan validitas eksternal.Validitas internal terkait dengan tingkat pengaruh perlakuan (treatment) atribut yang ada terhadap kemampuan berpikir kritis matematika siswa, yang didasarkan atas ketepatan prosedur dan data yang dikumpulkan serta penarikan kesimpulan.Sedangkan validitas eksternal terkait dengan dapat tidaknya hasil penelitian ini untuk digeneralisasikan pada subyek lain yang tidak memiliki kondisi dan karakteristik sama. Penelitian ini menggunakan metode percobaan (experiment) dengan rangcangan/disain faktorial $2 \times 2$ sebagai berikut : 
Tabel 3. Rancangan Penelitian

\begin{tabular}{cccc} 
& \multicolumn{2}{c}{ Metode Pembelajaran } \\
Minat Belajar & $\begin{array}{c}\text { Think Pair Share } \\
\left(\mathrm{A}_{1}\right)\end{array}$ & $\begin{array}{c}\text { Konvensional } \\
\left(\mathrm{A}_{2}\right)\end{array}$ & TOTAL \\
& $\mathrm{A}_{1} \mathrm{~B}_{1}$ & $\mathrm{~A}_{2} \mathrm{~B}_{1}$ & $\sum \mathrm{B}_{1}$ \\
Tinggi $\left(\mathrm{B}_{1}\right)$ & $\mathrm{A}_{1} \mathrm{~B}_{2}$ & $\mathrm{~A}_{2} \mathrm{~B}_{2}$ & $\sum \mathrm{B}_{2}$ \\
\hline Rendah $\left(\mathrm{B}_{2}\right)$ & $\sum \mathrm{A}_{1}$ & $\sum \mathrm{A}_{2}$ & $\sum$ TOTAL \\
\hline TOTAL &
\end{tabular}

$\mathbf{A}_{1} \mathbf{B}_{1}$ : Metode pembelajaran Think Pair Sharedengan minat belajar tinggi.

$\mathbf{A}_{1} \mathbf{B}_{2}$ : Metode pembelajaran Think Pair Sharedengan minat belajar rendah.

$\mathbf{A}_{2} \mathbf{B}_{1}$ : Metode pembelajaran Konvensionaldengan minat belajar tinggi.

$\mathbf{A}_{2} \mathbf{B}_{2}$ : Metode pembelajaran Konvensionaldengan minat belajar rendah.

Dalam penelitian ini sampel diambil sebanyak 60 orang siswa yang terbagi atas dua kelompok yaitu 30 orang siswa sebagai kelompok eksperimen dan 30 orang siswa sebagai kelompok kontrol. Instrumen yang digunakan adalah instrument tes dalam bentuk essay yang terlebih dahulu divalidasi secara empiris. Data yang diperoleh dianalisis terlebih dahulu dengan uji persyaratan analisis yaitu uji normalitas dan uji homogenitas.Berdasarkan keterpenuhan kriteia dalan uji persyaratan analisis data, kemudian dilanjutkan dengan analisis inferensial untuk pengujian hipotesis penelitian. Adapun analisis inferensial dalam penelitian ini adalah dengan uji anova dua arah dan uji lanjut dengan Tukey Test.

\section{HASIL DAN PEMBAHASAN}

\section{Hasil}

Secara deskriptif, data hasil penelitian ini dapat dinyatakan dalam tabel di bawah ini :

\section{Tabel 4. Data Hasil Penelitian}

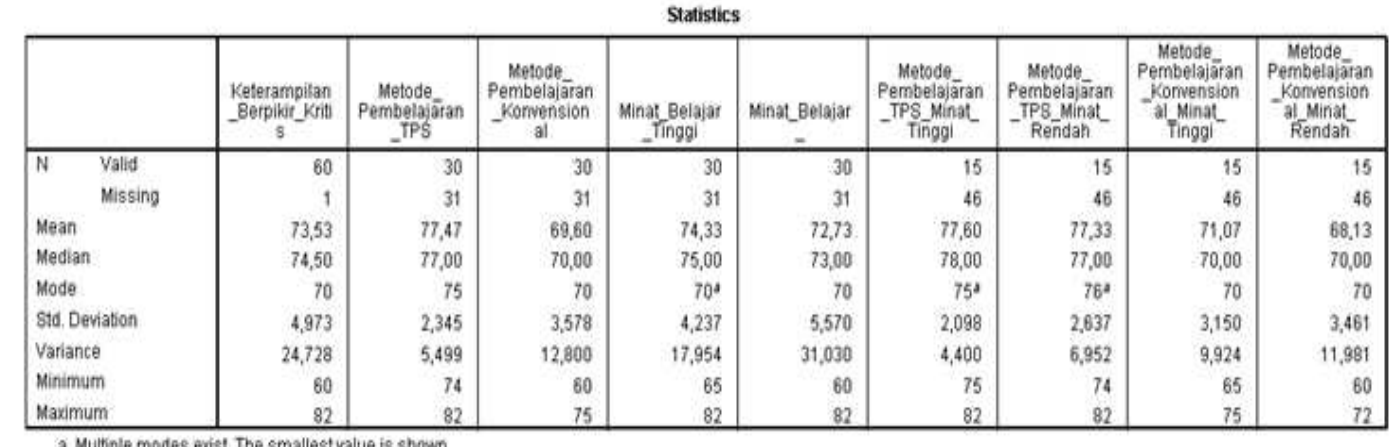

Berdasarkan tabel di atas, pengukuran data kemampuan berpikir kritis Matematika menggunakan instrumen tes obyektif berbentuk uraian (essay test) dengan 10 buah butir soal. Masing-masing butir diberi skor 1 hingga 10, sehingga rentang perolehan skor responden adalah 10 sampai dengan 100. Responden kelompok eksperimen sebanyak 30 siswa, yang diajarkan dengan metode pembelajaran kooperatif Think Pair Share dengan minat belajar berprestasi yang berbeda, dan responden kelompok yang diajar dengan metode pembelajaran konvensional sebanyak 30 siswa juga dengan minat belajar yang berbeda. Skor empiris tertinggi 82 dan terendah 60. Dari perhitungan statistik diperoleh nilai ratarata 73,53 , median 74,50 , modus 70 , standar deviasi 4,973 dan varians 24,7 . Hasil 
perhitungan secara lebih lengkap dapat dilihat pada Tabel 4 tersebut. Nilai rata-rata 73,53 menyatakan bahwa rata-rata siswa memperoleh nilai yang relatif cukup baik. Nilai standar deviasi sebesar 4,973 menyatakan bahwa kemampuan berpikir kritis Matematika yang diberikan pada siswa yang diajar dengan menggunakan metode pembelajaran Think Pair Share dan metode pembelajaran konvensional tidak banyak beragam.

\section{Pengujian Hipotesis Penelitian}

Analisis terhadap data kemampuan berpikir kritis Matematika siswa dilakukan dengan menggunakan uji ANOVA dua arah yang proses perhitungannya dibantu dengan program SPSS version 16.0 for Windows. Hasil uji ANOVA tersebut kemudian dilanjutkan dengan uji lanjut untuk mengetahui signifikansi perbedaan diantara masing-masing kelompok secara signifikan (simple effect). Adapun ringkasan hasil analisis data dengan menggunakan uji ANOVA dapat dilihat pada tabel berikut ini:

Tabel 5.Ringkasan Hasil ANOVA

Tests of Between-Subjects Effects

Dependent Variable:Berpikir_Kritis
\begin{tabular}{|l|r|r|r|r|r|}
\hline Source & $\begin{array}{r}\text { Type III Sum } \\
\text { of Squares }\end{array}$ & df & Mean Square & \multicolumn{1}{c|}{ F } & Sig. \\
\hline Corrected Model & $993,333^{a}$ & 3 & 331,111 & 39,824 &, 000 \\
Intercept & 324429,067 & 1 & 324429,067 & 39020,6 &, 000 \\
A & 928,267 & 1 & 928,267 & 111,647 &, 000 \\
B & 38,400 & 1 & 38,400 & 4,619 &, 036 \\
A*B & 26,667 & 1 & 26,667 & 3,207 &, 079 \\
Error & 465,600 & 56 & 5,314 & & \\
Total & 325888,000 & 60 & & & \\
Corrected Total & 1458,933 & 59 & & & \\
\hline
\end{tabular}

a. R Squared $=, 681$ (Adjusted R Squared $=, 664$ )

\section{Pengujian Hipotesis Pertama: Terdapat Pengaruh Metode Pembelajaran terhadap Kemampuan Berpikir Kritis Matematika.}

Hipotesis diuji dengan melihat koefisien signifikan.Jika nilai Sig $>0,05$ maka $\mathrm{H}_{0}$ diterima dan $\mathrm{H}_{1}$ otomatis ditolak. Jika nilai $\mathrm{Sig}<0,05$ maka $\mathrm{H}_{1}$ diterima dan $\mathrm{H}_{0}$ otomatis ditolak.

Dari pengujian dengan SPSS versi 16.0 for Windows di atas didapat Sig untuk metode pembelajaran kooperatif sama dengan $0,000<0,05$ dan $\mathrm{F}_{\text {hitung }}$ $(111,647)>F_{\text {tabel }}(4,20)$. Dengan demikian dapat disimpulkan terdapat pengaruh metode pembelajaran terhadap kemampuan berpikir kritis Matematika secara signifikan. Dengan kata lain kemampuan berpikir kritis Matematika dipengaruhi oleh penggunaan metode pembelajaran yang dipakai.

2. Pengujian Hipotesis Kedua: Terdapat Pengaruh Minat Belajar terhadap Kemampuan Berpikir Kritis Matematika.

Hipotesis diuji dengan melihat koefisien signifikan. Jika nilai Sig $>0,05$ maka $\mathrm{H}_{0}$ diterima dan $\mathrm{H}_{1}$ otomatis ditolak. Jika nilai $\mathrm{Sig}<0,05$ maka $\mathrm{H}_{1}$ diterima dan $\mathrm{H}_{0}$ otomatis ditolak.

Dari pengujian dengan SPSS versi 16.0 for Windows di atas didapat Sig untuk tingkat minat belajar berprestasi dengan $0,036<0,05$ dan $F_{\text {hitung }}(4,619)>$ $F_{\text {tabel }}(4,20)$. Berdasarkan perhitungan ini dapat disimpulkan terdapat pengaruh minat belajar terhadap kemampuan berpikir kritis Matematika secara signifikan. 
Dengan kata lain kemampuan berpikir kritis Matematika siswa dipengaruhi oleh minat belajar yang dimilikinya.

\section{Pengujian Hipotesis Ketiga: Terdapat Pengaruh Interaksi Metode Pembelajaran dan Minat Belajar terhadap Kemampuan Berpikir Kritis Matematika.}

Hipotesis diuji dengan melihat koefisien signifikan.Jika nilai Sig $>0,05$; maka $\mathrm{H}_{0}$ diterima dan $\mathrm{H}_{1}$ ditolak. Jika nilai $\mathrm{Sig}<0,05$; maka $\mathrm{H}_{1}$ diterima dan $\mathrm{H}_{0}$ otomatis ditolak.

Dari pengujian dengan SPSS version 16.0 for Windows di atas, didapat nilai Sig untuk metode pembelajaran kooperatif dan minat belajar sebesar 0,079>

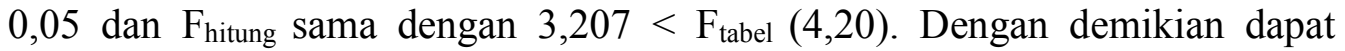
disimpulkan tidak terdapat pengaruh interaksi metode pembelajaran dan minat belajar terhadap kemampuan berpikir kritis Matematika secara signifikan. Dengan kata lain, kemampuan berpikir kritis Matematika tidak dipengaruhi oleh penggunaan metode pembelajaran dan minat belajar secara singnifikan. Berdasarkan hasil uji ANOVA ini, terlihat bahwa interaksi yang terjadi antara metode pembelajaran dan minat belajar terhadap kemampuan berpikir kritis Matematika merupakan interaksi yang tidak signifikan, karena tidak terdapat interaksi yang signifikan, maka tidak perlu dilakukan analisis lanjut untuk melihat simple effect di antara sub-sub faktor yang membangun interaksi tersebut.

\section{Interpretasi Hasil Penelitian}

Mengacu pada hasil penelitian dan didukung oleh analisis statistik untuk penelitian tentang kemampuan berpikir kritis Matematika, diperoleh simpulan bahwa data berasal dari populasi berdistribusi normal dan berasal dari varians yang sama (homogen). Dengan demikian maka data yang ada telah memenuhi uji persyaratan analisis data. Mengacu pada hal tersebut maka penelitian dapat dilanjutkan menuju pengujian hipotesis. Dari pengujian hipotesis tersebut dapat dianalisis bahwa:

1. Terdapat pengaruh metode pembelajaran terhadap kemampuan berpikir kritis Matematika. Dari pengujian hipotesis diperoleh bahwa nilai signifikansi (Sig) adalah 0,000 dan $F_{\text {hitung }}=111,647$ sedangkan $F_{\text {tabel }}=4,20$. Karena nilai $\operatorname{Sig}<0,05$ dan $F_{\text {hitung }}>F_{\text {tabel }}$ maka $\mathrm{H}_{0}$ ditolak dan $\mathrm{H}_{1}$ diterima, yang berarti terdapat pengaruh yang signifikan antara variabel bebas A (penggunaan metode pembelajaran) terhadap variabel terikat $\mathrm{Y}$ (kemampuan berpikir kritis Matematika). Secara operasional, kemampuan berpikir kritis Matematika diukur melalui suatu tes obyektif berbentuk uraian (essay test) dan dengan tes tersebut seorang siswa dituntut untuk mampu menjawab soal secara tertulis sesuai dengan kemampuan yang dimilikinya. Dari uraian teoritis tersebut dapat diasumsikan bahwa kemampuan berpikir kritis Matematika seorang siswa sangat dipengaruhi oleh penggunaan metode pembelajaran pada ruang-ruang kelas, yang dalam penelitian ini mengacu pada penggunaan Think Pair Shareyang lebih dominan ketimbang konvensional.Berdasarkan informasi kuantitatif dan teori tersebut di atas, maka peneliti berkesimpulan bahwa metode pembelajaran Think Pair Share mempunyai pengaruh yang positif dan signifikan terhadap kemampuan berpikir kritis Matematika seorang siswa. 
2. Terdapat pengaruh minat belajar terhadap kemampuan berpikir kritis Matematika siswa. Berdasarkan pengujian hipotesis diperoleh bahwa nilai signifikansi $(\mathrm{Sig})$ adalah 0,036 dan $\mathrm{F}_{\text {hitung }}=4,619$ sedangkan $\mathrm{F}_{\text {tabel }}=4,20$. Karena nilai Sig $<0,05$ dan $\mathrm{F}_{\text {hitung }}>\mathrm{F}_{\text {tabel }}$ maka $\mathrm{H}_{0}$ ditolak dan $\mathrm{H}_{1}$ diterima, yang berarti terdapat pengaruh yang signifikan antara variabel bebas $\mathrm{B}$ (minat belajar) terhadap variabel terikat Y (kemampuan berpikir kritis Matematika). Secara operasional, kemampuan berpikir kritis Matematika diukur melalui suatu tes tertulis berbentuk uraian (essay test) dan dengan tes tersebut seorang siswa dituntut untuk dapat menjawab soal yang diberikan secara tertulis berdasarkan kemampuan dan pengalaman belajarnya. Berdasarkan uraian teoritis tersebut bisa diasumsikan bahwa semakin baik minat belajar seorang siswa, maka semakin tinggi pula kemampuan berpikir kritis Matematika yang akan didapatnya kelak, begitupun sebaliknya. Seorang siswa yang memiliki minat belajar tinggi dalam belajar, tentu akan lebih mudah baginya dalam mengikuti proses pembelajaran Matematika, dan mempengaruhi hasil belajar yang akan didapatnya. Seorang siswa yang mempunyai minat belajar tinggi, cenderung optimal dalam belajar, sehingga cenderung beroleh hasil yang tinggi pada akhir pembelajaran. Merujuk pada informasi kuantitatif dan teori tersebut di atas, maka peneliti berkesimpulan bahwa minat belajar seorang siswa mempunyai pengaruh yang positif dan signifikan terhadap kemampuan berpikir kritis Matematika nya.

3. Tidak terdapat pengaruh interaksi penggunaan metode pembelajaran kooperatif dan minat belajar terhadap kemampuan berpikir kritis Matematika. Berdasarkan pengujian hipotesis diperoleh bahwa nilai signifikansi (Sig) adalah 0,079 dan $F_{\text {hitung }}=3,207$ sedangkan $F_{\text {tabel }}=4,20$. Karena nilai $\operatorname{Sig}<0,05$ sedangkan $F_{\text {hitung }}>$ $\mathrm{F}_{\text {tabel }}$ maka $\mathrm{H}_{0}$ ditolak dan $\mathrm{H}_{1}$ diterima, yang berarti tidak terdapat pengaruh interaksi yang signifikan antara variabel bebas A (penggunaan metode pembelajaran) dan variabel bebas B (minat belajar) terhadap variabel terikat $\mathrm{Y}$ (kemampuan berpikir kritis Matematika). Berdasarkan uraian teori sebelumnya, maka dapat diambil kesimpulan bahwa penggunaan metode pembelajaran dapat mempengaruhi kemampuan berpikir kritis Matematika siswa. Metode pembelajaran dengan menggunakan Think Pair Share, akan membuat seorang siswa merasa nyaman dan interaktif dalam proses pembelajaran, karena akan menghilangkan kemonotonan dalam proses belajar dengan cara berinteraksi dengan guru dan teman sejawat (peer group) lewat display yang disajikan, dalam mengikuti pelajaran dalam ruang kelas. Selanjutnya, bila seorang siswa merasa nyaman dengan metode pembelajaran yang diberikan oleh seorang guru dalam ruang kelas, ditunjang oleh minat yang baik dalam belajarnya, maka diharapkan hasil belajar yang akan dicapai berkembang secara optimal, karena hambatan berupa kejenuhan dalam belajar dan sikap yang apriopri dapat diatasi. Kondisi ini pada akhirnya diharapkan dapat memberikan sumbangan positif terhadap hasil belajarnya kelak. Namun pada kenyataannya, masing-masing varibel tidak memiliki pengaruh interaksi terhadap variabel terikat. Dari informasi kuantitatif dan tinjauan teori di atas, maka peneliti berkesimpulan bahwa kemampuan berpikir kritis Matematika dipengaruhi oleh penggunaan metode pembelajaran kooperatif yang digunakan dan minat belajarnya, namun pengaruh interaksi diantara kedua variabel bebas tersebut, tidak ada. 


\section{SIMPULAN, IMPLIKASI DAN SARAN Simpulan}

Merujuk pada hasil pengujian hipotesis penelitian dan analisis pengolahan data pada bab IV, maka dapat disimpulkan sebagai berikut:

1. Terdapat pengaruh yang signifikan penggunaan metode pembelajaran kooperatif terhadap kemampuan berpikir kritis Matematika siswa SMP Negeri di Kecamatan Tebet, Jakarta Selatan Barat. Hal tersebut dibuktikan oleh $\mathrm{F}_{\text {hitung }}=$ 111,647 dan $\mathrm{Sig}=0,000<0,05$. Ini berarti bahwa kemampuan berpikir kritis Matematika siswa dipengaruhi oleh penggunaan metode pembelajaran yang digunakan. Oleh karena itu penggunaan metode pembelajaran merupakan variabel yang penting untuk diperhatikan dalam memprediksi kemampuan berpikir kritis Matematika siswa.

2. Terdapat pengaruh yang signifikan minat belajar terhadap kemampuan berpikir kritis Matematika siswa SMP Negeri di Kecamatan Tebet, Jakarta Selatan. Hal tersebut dibuktikan oleh $\mathrm{F}_{\text {hitung }}=4,619$ dan $\mathrm{Sig}=0,036<0,05$. Ini berarti bahwa makin tinggi minat belajar seorang siswa, makin tinggi pula kemampuan berpikir kritis Matematika-nya. Sebaliknya, makin rendah minat belajar seorang siswa, makin rendah pula kemampuan berpikir kritis Matematika-nya. Oleh karena itu minat belajar merupakan variabel yang penting untuk diperhatikan dalam memprediksi kemampuan berpikir kritis Matematika seorang siswa.

3. Tidak terdapat pengaruh interaksi yang signifikan metode pembelajaran dan minat belajar terhadap kemampuan berpikir kritis Matematika siswa SMP Negeri di Kecamatan Tebet, Jakarta Selatan. Hal tersebut dibuktikan dengan $F_{\text {hitung }}=3,207$ dan Sig $=0,079>0,05$. Dengan demikian berarti kemampuan berpikir kritis Matematika siswa tidak ditentukan oleh interaksi metode pembelajaran dan minat belajar.

\section{Implikasi}

Dari hasil penelitian ditemukan bahwa tidak terdapat interaksi pengaruh metode pembelajaran kooperatif dan minat belajar terhadap kemampuan berpikir kritis Matematika, walaupun pada masing-masing variabel terdapat pengaruh yang signifikan. Hal ini karena dalam proses belajar untuk berpikir kritis Matematika yang menggunakan metode pembelajaran kooperatif, siswa diajar belajar melalui konsep atau alam pemikiran yang sudah dipahami oleh siswa sebelumnya lewat belajar dengan teman sebaya (peer teaching). Dalam konsep metode pembelajaran kooperatif dituntut kemampuan seorang guru dalam mengatur ruang kelas secara sistematis, sehingga siswa diharapkan mampu belajar secara aktif dengan guru dan teman sebaya berdasarkan bahan yang disajikan, yang pada akhirnya kemonotonan dalam proses pembelajaran dapat diminimalisir.

Berdasarkan hasil temuan dalam penelitian ini, maka dalam kapasitasnya sebagai seorang pendidik, guru Matematika harus mampu memahami minat belajar dari masing-masing peserta didik agar dapat dilakukan pemilahan dan perlakuan yang tepat dalam kegiatan pembelajaran. Sementara dalam kapasitasnya sebagai pengajar, maka seorang guru matematika harus mampu mendisain rancangan kegiatan pembelajaran dengan memilih metode pembelajaran kooperatif yang sesuai dengan minat belajar yang dimiliki masing-masing siswa.

Hasil penelitian menunjukkan bahwa secara umum penggunaan metodemetode pembelajaran kooperatif dapat memberikan kontribusi perolehan 
kemampuan berpikir kritis Matematika yang lebih baik ketimbang metode pembelajaran individual dengan guru sebagai pusatnya (teacher-centered). Dengan demikian maka dalam implikasi dalam upaya peningkatan hasil belajar Matematika, hendaknya para guru perlu menerapkan metode pembelajaran alternatif seperti kooperatif/kolaboratif dalam proses kegiatan belajar Matematika.

\section{Saran}

Berdasarkan simpulan dan implikasi penelitian, maka beberapasaran terkait yang dapat penulis sampaikan pada penelitian ini adalah:

1. Kemampuan berpikir kritis Matematika siswa yang belajar dengan metode pembelajaran kooperatif disarankan untuk dapat diterapkan dalam pembelajaran tingkat menengah (SMP dan SMA/SMK), karena itu guru Matematika hendaknya memperbanyak pengetahuan teori dari metode pembelajaran yang bervariatif dan berlatih untuk dapat membiasakan diri menggunakan metode tersebut secara menyenangkan dan kreatif.

2. Diperlukan pelatihan guru Matematika dalam mengoptimalkan kemampuan memberikan pelajaran lewat metode pembelajaran tertentu.

3. Pembekalan teori-teori, konsep-konsep dan aspek-aspek yang dimiliki seorang pendidik yang berhubungan dengan pelajaran Matematika, hendaknya perlu dikembangkan dan ditingkatkan.

4. Guru hendaknya dapat memilah dan menumbuhkan minat belajar siswa, dengan cara menstimulir siswa untuk dapat lebih menyenangi mata pelajaran Matematika yang diajarkannya sehingga dapat menumbuhkan minat belajar yang baik pada diri siswa untuk mengikuti proses pembelajaran.

\section{DAFTAR PUSTAKA}

Lie, Anita. 2002. Cooperative Learning (Mempraktikkan Cooperative Learning Di Ruang-Ruang Kelas).Jakarta : PT. Gramedia.

Suherman, Eman. 2003. Strategi Pembelajaran Kontemporer. Bandung: Universitas Negeri Jakarta.

Slameto. 2003. Belajar dan Faktor-Faktor yang Mempengaruhinya.Jakarta: Rineka Cipta.

Ledlow, Susan. Using Think-Pair-Share in The College Classroom, [ONLINE] Tersedia: http://www.clte.asu.edu/active/usingtps.pdf, Diakses, 13 Juli 2013.

Angelo, Thomas. A \& Patricia Cross. 1995. Classroom Assessment Techniques: A Handbook for College Teachers, 2nd edition. 